\title{
FACTORS INFLUENCING RESEARCH \& DEVELOPMENT EXPENDITURES OF MANUFACTURING COMPANIES OF BANGLADESH
}

\author{
Mousumi Rani Pal ${ }^{1}$, Md. Sohel Rana ${ }^{2}$, Ruksana Parvin ${ }^{3}$ \\ Power Grid Company of Bangladesh Ltd, Bangladesh ${ }^{1}$ \\ Jahangirnagar University, Savar, Dhaka, Bangladesh ${ }^{2}$ \\ German University Bangladesh, Gazipur, Bangladesh ${ }^{3}$
}

\begin{abstract}
The objective of this study is to identify the factors that have an impact on research and development expenditures of manufacturing companies of Bangladesh. Data for the year 2013 to 2016 were used to accomplish the purpose. Total 32 companies have been selected from seven manufacturing industries. All of these companies are listed in DSE. Panel data analysis has been employed to examine the data. Dependent variable of this study is $R \& D$ expenditures intensity whereas independent variables are classified into two categories. They are firm specific factors and corporate governance factors. The results indicate that experienced firms are intended to spend more on $R \& D$. Gross profit and firm size have significant negative association with $R \& D$ intensity. Leverage has significant impact on $R \& D$ of sample firms with positive coefficient. Number of independent directors in the board has significant negative correlation with firm's $R \& D$ expenditures. Sample size is a key limitation of this study. So far most of the empirical study considers either firm specific factors or corporate governance factors. This study is an attempt that takes into account both kind of factors. It will provide a glimpse of what factors can determine the $R \& D$ expenditure except industry type.
\end{abstract}

Keywords: Research and Development Expenditure, Innovation, Corporate governance factors, Firm specific factors, Manufacturing industry

\section{Introduction}

Research and development is one of the momentous segment of a company's business activities. Search plays lead role for organizational evolvement and prosperity (Chen \& Miller, 2007). Conducting research in proper way accelerate the desired success. Scientific research leads to technological innovation as well as economic growth (Fleming \& Sorenson, 2004). R\&D not merely generate new information, it also helps a firm to make the best use of present information (Cohen \& Levinthal, 1989). And these are the activities by which a company survives in long run.

Undoubtedly, competition is increasing in today's business world. Because of intensive competition level, the performance of a company on the arena of innovation becomes crucially important. Basically firms are differentiated by the way of their search from others (Katila \& Ahuja, 2002). 
Most of the times innovation becomes major causes for getting positive economic benefit (Kane, Ubilava, \& Xu, 2007). Investment in research and development is quite risky in nature and involves a long period of time (Chen \& Hsu, 2009). Though, R\&D activity has the strong potentiality to bring positive changes, it is also fraught with risk and so can be the cause of magnitude loss (Greve, 2003). Bring to light on the influencing factors of research and development may be in great help to understand it properly and reducing related uncertainty.

The aim of this study is to ascertain factors that influence $R \& D$ expenditures of manufacturing companies. In this paper, factors are divided in two categories. One category contains firm specific factors and another contains corporate governance factors.

Technological change has been given less importance in developing countries in comparison to developed countries (Subodh, 2002). While economic growth of a country is decided by the improvement in technology (Ferdaous \& Rahman, 2017). Investment in $R \& D$ can bring technological change. The economy of Bangladesh is growing significantly. A growing economy must have to focus on its manufacturing sector to continue this progress. Manufacturing sector need to make investment on $\mathrm{R} \& \mathrm{D}$ for improving the business besides competing successfully in the market. Determining influencing factors of $\mathrm{R} \& \mathrm{D}$ will smooth this whole activity.

The notion of $R \& D$ expenditure is not very old in the context of Bangladesh (Ferdaous \& Rahman, 2017). Yet many companies do not incur any $R \& D$ expenditure. It is one of the major obstacles for enhancing economic growth. Some particular industry requires heavy investment on R\&D. Before enhancing $R \& D$ expenditures, the influencing factors should be identified. That will be helpful for manufacturing firms to understand the situation and ameliorate their R\&D activity. The result of the study will help the policy maker to understand the situation more clearly and take decision about incurring research \& development expenditure.

Some particular features make this paper isolate from others. Many previous literatures took place on a particular industry such as family business group (Min \& Smyth, 2015), electronic industry (Chen H. L., 2012), agribusiness companies (Kane et al., 2007), pharmaceutical industry (Mahlich \& RoedigerSchluga, 2006) etc. And some research were about manufacturing industry by Pamukcu and Utku-Ismihan (2009), Yanghua (2010) etc. These studies concentrated on the market of South Korea, Taiwan, Malaysia, France, Turkey, Japan etc.

One study took place in Bangladesh by Ferdaous and Rahman (2017) which examined effects of R\&D expenditure on firm performance in pharmaceuticals industry. Very few study is available about influencing factors of R\&D expenditures as well as about manufacturing industry in Bangladesh. This paper attempts to lessen that research gap and contribute to unwrap the determining factors of $R \& D$ in manufacturing industries of Bangladesh. Next differentiating context is type of investigative factors. Most of the study 
used either firm specific factors or some factors of corporate governance. Such as Chen and Hsu (2009) examined the relationship among family ownership, board independence and R\&D investment. Some Studies investigated the relation between corporate governance and innovation (Goyer, 2001; Honore, Munari, \& Potterie, 2015 ; Othman \& Ameer, 2009). Becker and Pain (2008) used industry characteristics like sales \& profitability, product market competition and some macroeconomic factors like interest and exchange rate to find the determining factors of R\&D performance. Kane et al. (2007) used firm specific factors; Subodh (2002) used market structure variables; Pamukcu and Utku-Ismihan (2009) used sector and firm level factors to investigate the inluencing factors of $R \& D$ ependitures in their study. This paper analyze both the firm specific factors and corpoate governance factors using a panel data analysis. And thus this study is going to mitigate the research gap of previous literatures. This will also be a new footprint of literature as determining factors of $R \& D$ expenditures in the context of Bangladesh.

After wards the paper is organized in following manner. Section 2 contains a concise review of prior relevant literature. Section 3 is about research methodology which comprises variables and hypotheses along with specification of model. After furnishing empirical result in section 4 , section 5 has drawn concluding comment with future research prospect.

\section{Literature Review}

Research and Development is also known as R\&D. Research and development expenditures
International Journal of Accounting \& Business Finance Vol.6.No.2 December 2020 Issue. pp. 33 - 54

signify the innovative factor and this is applicable for a company, an industry or a country. R\&D is defined on OECD Factbook (2015-2016) as "Research and development comprise creative work undertaken on a systematic basis in order to increase the stock of knowledge (including knowledge of man, culture and society) and the use of this knowledge to devise new applications." Involvement with R\&D activity can be used to measure the technological strength or competitive advantage of a company or a country (Yanghua, 2010). Research and development expenditures help to lessen existing product's cost by exploring new process and increase the option to choose more products for consumers by innovating new product (Zemplinerova \& Hromadkova, 2012)

In recent time, $R \& D$ has been given significant weight by policy makers and researchers for ensuring long term economic progress (Becker \& Pain, 2008). R\&D helps a company to increase its wealth and attain sustainable development. A company can enjoy advanced quality and quantity of production because of successful innovation that results from R\&D activity (Khan \& Khattak, 2014). The challenge regarding competition faced by the firms at micro level (Yanghua, 2010) can be conquered by $R \& D$ activity.

$\mathrm{R} \& \mathrm{D}$ activity is notably uncertain in nature and intensive in sunk cost (Driver \& Guedes, 2012). According to agency theory, managers are often risk averse and may be decided to choose the option that is better for himself only (Panda \& Leepsa, 2017). Board monitoring may encourage risk aversion propensity of 
managers which will lead to decrease the investment on R\&D (Guldiken \& Darendeli, 2016). It is quite difficult for corporation to predict future outcome precisely which subsequently originate a complex situation in relation to R\&D investment. Action taken by independent board might be in help of reducing this complexity and prioritize increasing of innovative capacity (Kor, 2006).

Investmentin R\&Dactivityhelpsmanufacturing firms to enhance competitive capability. As R\&D performs more responsibility to commence new and innovative project in comparison to other function (Nohria \& Gulati, 1996), without this it would be cumbersome to indemnify sustainable development. Manufacturing sector is such significant that it is account for a major portion of business sector R\&D (Becker \& Pain, 2008).

A large number of empirical literatures have been conducted on R\&D based on different market in different country. Literary works on $R \& D$ can be partitioned into two broad categories. One branch focuses on relationship between firm performance and R\&D activity. While another branch of research is about determining factor of $R \& D$ expenditures. Empirical work on later one is more relevant to the current study.

Researcher investigated influencing factor of $\mathrm{R} \& \mathrm{D}$ in different industry. For instance, Lee and Hwang (2003) examined the determinants of corporate R\&D investment by using financial data of 515 firms of both IT and non IT industry. The study used ordinary regression model, fixed effect model and random effect model. The study found that asset, sales growth rate, subsidy are positively correlated with $R \& D$ expenditure while dividend was negatively correlated. In another research, NISHI (2015) examined the effect of different board structures on R\&D investment. Necessary data were collected from $R \& D$ database for Japanese electronic corporations for the financial year 2010-2014. Panel fixed effect model and Tobit model were used for analysis. The study concluded that outside director has negative association with $\mathrm{R} \& \mathrm{D}$ intensity. Apart from this, review of some previous literatures is concisely narrated in the following table. 
Table 1. Recent studies about influencing factors of R\&D

\begin{tabular}{|c|c|c|c|c|}
\hline Author (Year) & Country & Sample size & Variable & Findings \\
\hline $\begin{array}{l}(\mathrm{Li} \text { m a } \mathrm{n} \text { i, } \\
2015)\end{array}$ & Turkey & $\begin{array}{l}765 \\
\text { observations for } \\
2008, \\
734 \\
\text { observations for } \\
2013\end{array}$ & $\begin{array}{l}\text { Dependent variable: binary } \\
\text { variable (1 if firm invest in } \\
\text { R\&D and } 0 \text { if firm does not } \\
\text { invest in R\&D) } \\
\text { Independent variable: Size, } \\
\text { square of size, total export } \\
\text { share, total national share, } \\
\text { total foreign ownership, } \\
\text { part of other bigger firm } \\
\text { (dummy variable), public } \\
\text { subsidy (dummy variable), } \\
\text { importance of costumers } \\
\text { (dummy variable), size } \\
\text { indicator }\end{array}$ & $\begin{array}{l}\text { R\&D is posi- } \\
\text { tively related with firm } \\
\text { size (sales) though incre- } \\
\text { ment is not linear to size. } \\
\text { After a threshold, R\&D } \\
\text { start to decrease if firm } \\
\text { size continue to increase. } \\
\text { Export share in } \\
\text { total sale, public support, } \\
\text { being part of bigger firm } \\
\text { have significant positive } \\
\text { relationship with depen- } \\
\text { dent variable. } \\
\text { National share } \\
\text { variable is negative and } \\
\text { significant to the depen- } \\
\text { dent variable. } \\
\text { Foreign own- } \\
\text { ership share has negative } \\
\text { association for } 2008 \text { and } \\
\text { significant positive associ- } \\
\text { ation for 2013. }\end{array}$ \\
\hline $\begin{array}{l}\text { (Othman \& } \\
\text { Ameer, 2009) }\end{array}$ & Malaysia & $\begin{array}{l}228 \text { firm-year } \\
\text { observations }\end{array}$ & $\begin{array}{l}\text { Dependent variable: R\&D } \\
\text { intensity (R\&D expenditure } \\
\text { over sales and R\&D } \\
\text { expenditure per employee as a } \\
\text { proxy for R\&D intensity) } \\
\text { Independent variable: Stock } \\
\text { option, Slack (ratio of selling, } \\
\text { general and administrative } \\
\text { expenses to sales), tenure of } \\
\text { CEO, experience of CEO } \\
\text { (dummy variable), R\&D } \\
\text { capacity, sales growth, } \\
\text { subsidiary, total sales to } \\
\text { average total assets, total cash } \\
\text { flow to sales ratio, ratio of } \\
\text { total debt to total assets, tax } \\
\text { exemption (dummy variable) }\end{array}$ & $\begin{array}{l}\text { SLACK and } \\
\text { sales growth have signif- } \\
\text { icant positive influence } \\
\text { on R\&D spending of the } \\
\text { firms. } \\
\text { Significant negative asso- } \\
\text { ciation } \\
\text { CEO character- } \\
\text { istics, tax exemption have } \\
\text { no significant effect on } \\
\text { R\&D expense. Stock op- } \\
\text { tion and total debt to total } \\
\text { asset variable are insignifi- } \\
\text { cant to dependent variable. }\end{array}$ \\
\hline
\end{tabular}




\begin{tabular}{|c|c|c|c|c|}
\hline $\begin{array}{l}\text { Guldiken \& } \\
\text { D a r en d e li, } \\
2016)\end{array}$ & USA & $\begin{array}{l}467 \text { firm-year } \\
\text { observations }\end{array}$ & $\begin{array}{l}\text { Dependent variable: R\&D } \\
\text { intensity (ratio of R\&D } \\
\text { expenditures to firm sales) } \\
\text { Independent variable: } \\
\text { Directors equity holding as a } \\
\text { proxy for board monitoring, } \\
\text { proportion of directors } \\
\text { appointed to the board } \\
\text { before the tenure of the CEO } \\
\text { (additional measure of board } \\
\text { monitoring), average board } \\
\text { tenure of outside directors } \\
\text { as a proxy for firm specific } \\
\text { human capital, total number } \\
\text { of managerial positions that } \\
\text { outside directors hold in the } \\
\text { same industry as a proxy } \\
\text { for industry specific human } \\
\text { capital } \\
\text { Control variable: CEO } \\
\text { duality, CEO equity, past firm } \\
\text { profitability, firm size, firm } \\
\text { leverage, firm age, a dummy } \\
\text { variable indicating, whether } \\
\text { the firm acquired another } \\
\text { firm in the high-tech industry } \\
\text { to have access to its R\&D } \\
\text { (1=acquired; } 0=\text { not acquired), } \\
\text { and board size }\end{array}$ & $\begin{array}{l}\text { R\&D intensity } \\
\text { does not decrease when } \\
\text { outside directors possess } \\
\text { high levels of firm-specific } \\
\text { human capital. } \\
\text { Outside direc- } \\
\text { tors' either firm- or indus- } \\
\text { try-specific human capital } \\
\text { does not increase the rate } \\
\text { at which board monitoring } \\
\text { increases firms' R\&D in- } \\
\text { tensity. }\end{array}$ \\
\hline $\begin{array}{l}\text { (Costa-Campi, } \\
\text { Duch-Brown, } \\
\& \text { Garcia- } \\
\text { Q u e v e d o }, \\
\text { 2014) }\end{array}$ & Spain & $\begin{array}{l}410 \\
\text { observations }\end{array}$ & 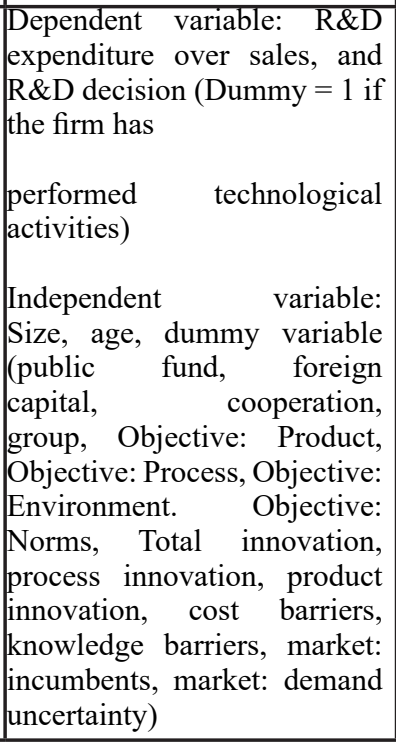 & $\begin{array}{l}\text { No positive re- } \\
\text { lationship between size } \\
\text { (number of employee) and } \\
\text { R\&D intensity. } \\
\text { New firms are } \\
\text { involved with R\&D more } \\
\text { than older firms. } \\
\text { Public fund has } \\
\text { positive effect on R\&D. } \\
\text { Firms giving } \\
\text { importance to process } \\
\text { innovation, invest large } \\
\text { amount in technological } \\
\text { activities. }\end{array}$ \\
\hline
\end{tabular}


International Journal of Accounting \& Business Finance Vol.6.No.2 December 2020 Issue. pp. 33 - 54

\begin{tabular}{|c|c|c|c|c|}
\hline \multirow[t]{3}{*}{$\begin{array}{l}\text { Kumar \& } \\
\text { A g g a r w a 1, } \\
2005)\end{array}$} & \multirow[t]{3}{*}{ India } & \multirow[t]{3}{*}{4209} & \multirow{3}{*}{$\begin{array}{l}\text { Dependent variable: R\&D/ } \\
\text { Sales } \\
\\
\text { Independent variable: Firm } \\
\text { size, technology import, } \\
\text { export, outward investment, } \\
\text { profit margin, multinational } \\
\text { affiliation (dummy), } \\
\text { technological opportunities } \\
\text { (dummy) }\end{array}$} & \multirow{3}{*}{$\begin{array}{l}\text { After a certain } \\
\text { point, R\&D spending rises } \\
\text { more than proportionately } \\
\text { with firm size. } \\
\text { Both export and } \\
\text { outward investment have } \\
\text { significant positive asso- } \\
\text { ciation with dependent } \\
\text { variable. } \\
\text { Profit margin } \\
\text { has significant negative } \\
\text { impact on R\&D. } \\
\text { Engineering and } \\
\text { chemical industries have } \\
\text { higher R\&D intensity in } \\
\text { comparison to other in- } \\
\text { dustries. }\end{array}$} \\
\hline & & & & \\
\hline & & & & \\
\hline $\begin{array}{l}\text { (Honore et al., } \\
2015)\end{array}$ & $\begin{array}{l}\text { European } \\
\text { Countries }\end{array}$ & $\begin{array}{l}373 \text { firm-year } \\
\text { observations }\end{array}$ & $\begin{array}{l}\text { Dependent variable: R\&D } \\
\text { intensity (R\&D expenditures/ } \\
\text { total sales) } \\
\text { Independent variable: } \\
\text { Limitations of anti-takeover } \\
\text { devices, shareholders' } \\
\text { consensus at the AGM, } \\
\text { remuneration linked to } \\
\text { financial performances, } \\
\text { limitation of severance pay } \\
\text { Control variable: Board } \\
\text { score, audit committee score, } \\
\text { operating income, intangible } \\
\text { assets, log intangible assets }\end{array}$ & $\begin{array}{l}\text { Except limita- } \\
\text { tion of severance pay, oth- } \\
\text { er independent variables } \\
\text { have significant negative } \\
\text { association with depen- } \\
\text { dent variable at } 5 \% \text { prob- } \\
\text { ability threshold. } \\
\text { Board score and } \\
\text { audit committee score are } \\
\text { positively significant at } \\
10 \% \text {. Intangible asset be- } \\
\text { came positively significant } \\
\text { at } 1 \% \text { probability. }\end{array}$ \\
\hline $\begin{array}{l}\text { (Chen \& Hsu, } \\
\text { 2009) }\end{array}$ & Taiwan & $\begin{array}{l}1,845 \\
\text { observations }\end{array}$ & $\begin{array}{l}\text { Dependent variable: Ratio of } \\
\text { R\&D expenditures to sales } \\
\text { Independent variable: Family } \\
\text { ownership, CEO duality, } \\
\text { independent director ratio } \\
\text { Control variable: Total assets, } \\
\text { return on asset, leverage, firm } \\
\text { risk, diversification, current } \\
\text { liquidity, institutional stock } \\
\text { ownership, management } \\
\text { stock ownership, firm age }\end{array}$ & $\begin{array}{l}\text { As family own- } \\
\text { ership has negative asso- } \\
\text { ciation with dependent } \\
\text { variable, so it discourages } \\
\text { long term R\&D invest- } \\
\text { ment. } \\
\text { The firms hav- } \\
\text { ing high family owner- } \\
\text { ship, more independent di- } \\
\text { rector, separate CEO and } \\
\text { chairman encourage R\&D } \\
\text { investment. }\end{array}$ \\
\hline
\end{tabular}




\begin{tabular}{|c|c|c|c|c|}
\hline $\begin{array}{ll}\text { Bhattacharya } \\
\& & \text { Bloch, } \\
2004) & \end{array}$ & Australia & $\begin{array}{l}1213 \\
\text { observations }\end{array}$ & $\begin{array}{l}\text { Dependent variable: Value of } \\
\text { innovation (one if the business } \\
\text { developed or introduced new } \\
\text { or substantially changed } \\
\text { products or services. } \\
\text { Otherwise, it is zero.) } \\
\text { Independent variable: } \\
\text { Business size (sales), profit, } \\
\text { growth, technology variable, } \\
\text { concentration, export, import }\end{array}$ & $\begin{array}{l}\text { Size (sales) has } \\
\text { positive impact on inno- } \\
\text { vation for full sample size. } \\
\text { In case of high } \\
\text { tech industries, market } \\
\text { concentration and export } \\
\text { intensity has significant } \\
\text { positive impact on inno- } \\
\text { vation. } \\
\text { Profitability sig- } \\
\text { nificantly increases inno- } \\
\text { vative activity in low tech } \\
\text { industries. }\end{array}$ \\
\hline $\begin{array}{l}\text { Min } \\
\text { Smyth, 2015) }\end{array}$ & $\mid \begin{array}{lllll}S & o & u & t & h \\
\text { Korea } & & & \end{array}$ & $\begin{array}{l}3,403 \text { firm-year } \\
\text { observations }\end{array}$ & $\begin{array}{l}\text { Dependent variable: R\&D } \\
\text { investment as a percentage of } \\
\text { firm assets } \\
\text { Independent variable: Growth } \\
\text { opportunity, leverage, } \\
\text { firm size, board payment, } \\
\text { controlling shareholder equity } \\
\text { ownership, operating cash } \\
\text { flow, foreign ownership, audit } \\
\text { committee, outside director, } \\
\text { subsidiary member, stock } \\
\text { return }\end{array}$ & $\begin{array}{l}\text { Growth oppor- } \\
\text { tunities, size of the firm } \\
\text { and payment to executive } \\
\text { board members have posi- } \\
\text { tive association with R\&D } \\
\text { intensity. } \\
\text { Leverage has a } \\
\text { negative effect on R\&D } \\
\text { intensity. }\end{array}$ \\
\hline $\begin{array}{l}\text { (Chen H. L., } \\
\text { 2012) }\end{array}$ & Taiwan & $\begin{array}{l}227 \\
\text { observations }\end{array}$ & $\begin{array}{l}\text { Dependent variable: Ratio of } \\
\text { R\&D expenditures to sales } \\
\text { Independent variable: Board } \\
\text { size, director's education level } \\
\text { and board meeting frequency } \\
\text { Control variable: Firm size, } \\
\text { firm performance, debt ratio, } \\
\text { institutional stock ownership }\end{array}$ & $\begin{array}{l}\text { R\&D invest- } \\
\text { ment is negatively cor- } \\
\text { related with board size but } \\
\text { has positive correlation } \\
\text { with director's education } \\
\text { level. } \\
\text { Though the } \\
\text { association with board } \\
\text { meeting frequency } \\
\text { is positive, but it is } \\
\text { insignificant. }\end{array}$ \\
\hline
\end{tabular}

\section{Research Methodology}

\subsection{Selection of Sample}

The research is conducted by taking sample from the manufacturing industries of Bangladesh listed in Dhaka Stock Exchange. Total seven sectors of manufacturing industry are chosen from all of the manufacturing industries. Some manufacturing industries are avoided because those don't have any expenditure on research and development. Among seven manufacturing industries some particular industries are given more importance than others. Since some industries require more investment on research and development, a large number of samples are chosen from pharmaceuticals and chemicals \& textile industry. Data are collected for period of 4 years. Time frame is extended from 2013 to 2016. Though there are 163 
companies in seven manufacturing industry, this study has strong balanced panel of 128 32 companies are taken as sample. Ultimately, firm-year observations. Because of data

unavailability, sample size is not large enough.

Table 2. Type of industry and no of company chosen

\begin{tabular}{|l|l|l|l|}
\hline No & Type of industry & Total No of Company & No of Company Chosen \\
\hline 1 & Cement & 7 & 2 \\
\hline 2 & Ceramic & 5 & 1 \\
\hline 3 & Engineering & 37 & 1 \\
\hline 4 & Food \& Allied & 17 & 7 \\
\hline 5 & Pharmaceuticals and Chemicals & 31 & 10 \\
\hline 6 & Miscellaneous & 13 & 1 \\
\hline
\end{tabular}

\begin{tabular}{|c|l|l|l|}
\hline 7 & Textile & 53 study, R\&D expenditglies included research \\
\hline Total & & 163 and development & $32^{\text {expenditure, product }}$ \\
\hline
\end{tabular}

\subsection{Sources of Data}

Information for the particular variable are collected from the annual report of the companies. Some information is also collected from the website of any particular company in case of absence of that information on annual report.

\subsection{Hypothesis development}

\section{1) R\&D intensity}

$\mathrm{R} \& \mathrm{D}$ intensity is used as dependent variable (Guldiken \& Darendeli, 2016; Othman \& Ameer, 2009). Several number of literatures mentioned in literature review section use this variable as a dependent variable. Moreover, research and development expenditure include several types of expenses. In this testing fee etc.

2) Age

Which organization has long-term experience, they are engaged in more innovative operation and have better scheme of generating new product and process (Subodh, 2002). As the time passes, the firm attains more knack and managerial capabilities (Pamukcu \& UtkuIsmihan, 2009). Experienced firms remain in advantageous position as they get more chances to accumulate the knowledge for future necessity. It is expected that there is a significant positive influence of age on undertaking R\&D activity. Chen \& Hsu (2009) used age to control for firm and ownership effects on the investment of research and development. Subodh (2002) also used age in his study to indicate experience of sample 
firms.

H1: There is a significant association between age and $R \& D$ intensity

\section{3) Gross Profit}

Innovation activities are taken place so that firms can enjoy enhancing profits (Pamukcu, 2003). Profit margin can act as an indicator of competitive environment that an entity has to face in different time (Kumar \& Saqib, 1996). In their study, they enunciate that profit margin helps to raise internal fund, which subsequently leads the possibility of having positive relationship with innovative operation. Subodh (2002) found positive and significant association between R\&D and profit margin in electronics industry, but it was insignificant in drug and pharmaceutical industry.

H2: There is a significant association between gross profit and $R \& D$ intensity

\section{4) Firm Value}

There is a relationship between firm's value and some strategic decision made by the firm like investment in R\&D. Literature mentioned above support this. Firm size determines whether the firm has the ability to invest in innovation. Firm size is used in several previous studies such as (Chen \& Hsu, 2009; Lee \& Hwang, 2003 ; Min \& Smyth, 2015).

H3: There is a significant association between firm value and $R \& D$ intensity

\section{5) Leverage Ratio}

Pursuing innovativeness require to show lower leverage ratio (Yanghua, 2010). Equity
International Journal of Accounting \& Business Finance Vol.6.No.2 December 2020 Issue. pp. 33 - 54

financing get more preference to debt financing in case of high asset specificity like R\&D investment (Williamson, 1988). Another thing is that when there will be more debt financing that means external financing, that may not be very helpful for the company to keep their information secure. Generally firm will not be willing to share their information about R\&D activities, as the firm may have to face loss in case of competitiveness (Min \& Smyth, 2015). Leverage was present on the literature conducted by Chen and Hsu (2009); Min and Smyth (2015).

H4: Leverage has significant association with $R \& D$ intensity

\section{6) Gender Diversity}

Now days, female directors are getting importance in corporate governance. Female directors use their knowledge and different strategies to get work done and assert their dominance (Burke, 2003).Female directors of an entity have higher performance record in attending meeting in comparison to male directors and preference is given to female directors when member of different monitoring related committees are ascertained (Adams \& Ferreira, 2009). It is expected that increasing number of female board member will have positive impact on firm's outcome as well as firm's R\&D activity.

H5: Gender diversity is significantly associated to $R \& D$ intensity

\section{7) Board of Director}

It depends on the board size whether the firm will get it's necessary funds or not (Chen H. L., 
2012). A large number of directors also make the situation easy for the firm to get access in external resources (Shapiro, Tang, Wang, \& Zhang, 2015). More directors in the board is one kind of good sign for the firm. As the firm can have different type of expertise. And the firm can make the best utilization of this opportunity. The firm may get wise decision from the directors in emergency. This variable was used in previous study by (Chen H. L., 2012).

H6: Board size is significantly associated to $R \& D$ intensity

\section{8) Independent Director}

A board having independent director is considered to be more stakeholders oriented and ensure stakeholder's interest (Goyer, 2001). According to this reference, the activities which reduce shareholder interest are avoided in the presence of independent director. In Bangladesh it is mandatory to have at least $1 / 5$ independent director in the board for manufacturing companies. Chen and $\mathrm{Hsu}$ (2009) exercise independent director along with another variable to investigate board independence.

H7: Independent director has significant association with $R \& D$ intensity

\section{9) Board Payment}

If payment to board member is fixed, and there is no other incentive then the board member will not be interested to engage in any risky activities (Min \& Smyth, 2015). As well as they will not be interested to think about R\&D
International Journal of Accounting \& Business Finance Vol.6.No.2 December 2020 Issue. pp. 33 - 54

expenditures. Moreover, shareholders will expect better performance from the board if the board get higher payment. Min \& Smyth (2015) used this variable in their study and depict that to meet the higher expectation, the board members will be more cautious about their performance.

H8: Payment to board members has significant association with $R \& D$ intensity

\section{0) Board Meeting Frequency}

Through board meeting board members can discuss with each other, determine operational issues and some other problem which leads to better decision-making process and better firm performance (Al-Daoud, Saidin, \& Abidin, 2016). Board meeting frequency was used by (Chen H. L., 2012) as independent variable in a study.

H9: Board meeting frequency has significant association with $R \& D$ intensity

\subsection{Regression Model}

Panel data analysis has been used to test the effect of corporate governance factors and firm specific factors on $R \& D$ expenditures. Hausman test is presented on the appendix to ensure brevity. The following empirical model has been developed by analyzing previous literature.

RDINT $=\alpha+\beta_{1}$ Age (AGE) $+\beta_{2}$ Gross Profit $(\mathrm{GP})+\beta_{3}$ Firm Value (FV) $+\beta_{4}$ Leverage $(\mathrm{LR})+\beta_{5}$ Gender Diversity (GD) $+\beta_{6}$ Board of Director (BOD) $+\beta_{7}$ Independent Director (ID) $+\beta_{8}$ Board Payment (BP) $+\beta_{9}$ Board Meeting Frequency $(\mathrm{BMF})+\varepsilon$ 
Table 3. Definition of variables

\begin{tabular}{|c|c|c|c|}
\hline Type of variable & Variables & Notation & Definition \\
\hline Dependent Variable & R\&D Expenditures Intensity & RDINT & $\begin{array}{l}\text { (R\&D expenditures/Sales) } \\
* 100\end{array}$ \\
\hline \multirow[t]{4}{*}{$\begin{array}{l}\text { Independent variable } \\
\text { (Firm specific factors) }\end{array}$} & Age & AGE & $\begin{array}{l}\text { Number of the years of } \\
\text { firm's incorporation }\end{array}$ \\
\hline & Gross Profit & GP & $\begin{array}{l}\text { Natural logarithm of gross } \\
\text { profit }\end{array}$ \\
\hline & Firm Value & $\mathrm{FV}$ & $\begin{array}{l}\text { Natural logarithm of total } \\
\text { asset }\end{array}$ \\
\hline & Leverage Ratio & LR & Debt to equity ratio \\
\hline \multirow{2}{*}{$\begin{array}{l}\text { I } \mathrm{n} \mathrm{d} \mathrm{e} \mathrm{p} \mathrm{e} \mathrm{n} \mathrm{d} \mathrm{e} \mathrm{n} \mathrm{t} \\
\text { variable (Corporate } \\
\text { governance factors) }\end{array}$} & Gender Diversity & GD & $\begin{array}{l}\text { Percentage of female board } \\
\text { members }\end{array}$ \\
\hline & Board of Director & BOD & $\begin{array}{l}\text { Total number of board of } \\
\text { director }\end{array}$ \\
\hline \multicolumn{2}{|l|}{ Independent Director } & ID & $\begin{array}{l}\text { Number of independent } \\
\text { director }\end{array}$ \\
\hline & Board Payment & $\mathrm{BP}$ & $\begin{array}{l}\text { Payment to board members/ } \\
\text { Assets }\end{array}$ \\
\hline & Board Meeting Frequency & $\mathrm{BMF}$ & $\begin{array}{l}\text { Number of board meeting } \\
\text { frequency }\end{array}$ \\
\hline
\end{tabular}

\section{Empirical Analysis and Finding}

\section{Descriptive statistics}

Table 4. Descriptive Statistics

\begin{tabular}{|l|l|l|l|l|l|}
\hline Variable & Obs & Mean & Std. Dev. & Min & Max \\
\hline RDINT & 128 & .171097 & .3728803 & 0 & 2.593537 \\
\hline AGE & 128 & 23.71875 & 15.51171 & 3 & 67 \\
\hline GP & 128 & 20.2524 & 1.226591 & 18.06701 & 23.71212 \\
\hline FV & 128 & 22.0342 & 1.107678 & 20.16417 & 24.2885 \\
\hline LR & 128 & 1.206641 & 1.52595 & .02 & 14.27 \\
\hline GD & 128 & .1968314 & .1697275 & 0 & .5 \\
\hline BOD & 128 & 7.007813 & 1.6577 & 4 & 11 \\
\hline ID & 128 & 1.796875 & .4918129 & 1 & 3 \\
\hline BMF & 128 & 9.8125 & 7.204275 & 4 & 58 \\
\hline BP & 128 & .0020567 & .002993 & 0 & .0249506 \\
\hline
\end{tabular}

Total number of observations $=128$ 
Descriptive statistics measure central tendency of data. Along with central tendency, it covers coefficients of dispersion like minimum, maximum, standard deviation. The average age of the selected firms is approximately 23 years, which evidence firms are well experienced. Maximum age of sample firms is 67 years while minimum age is 3 years. That means data of this study represent both new and experienced firms. The mean value of leverage ratio is 1.2066 which indicates companies considered in this study hold high amount of debt in comparison to their equity.

Percentage of female director in the board varies from 0 to 50 percentages of total board members. Standard deviation is 0.1697 , which is near to the mean value .1968. This result alludes sample firms have very small number of female director in the board. All sample companies have at least one independent director with maximum number of three. Average number of board meeting is approximately 10 that clearly indicate board members meet several times to discuss different crucial issues. Minimum value of board payment is 0 as some company didn't pay at all to their directors in that respective year. Average R\&D intensity represent a small portion of sales are R\&D expenditures. Maximum expenditures of $R \& D$ is $2.59 \%$ of sales.

\subsection{Regression Analysis}

The result of hausman test (appendix table A4) shows that fixed effect model is suitable
International Journal of Accounting \& Business Finance Vol.6.No.2 December 2020 Issue. pp. 33 - 54

for the analysis. To find out the relationship between dependent and independent variables panel data analysis has been conducted. $\mathrm{R}$ square of the fixed effect model is .8323 which indicates every independent variables of this model explain approximately $83 \%$ of the variability of RDINT of selected manufacturing companies of

Bangladesh. Value of " $F$ " is higher than the value of "Prob $>F$ ". Value of "F" is 47.98 that indicates this model significantly explain the variations. The results expose that significant level is below $5 \%$. So it can be said that $\mathrm{F}$ statistic and $\mathrm{P}$ value are significantly strong enough to influence the dependent variable of this study. The study result shows that dependent variable RDINT has significant relationship with five independent variables namely AGE, GP, FV, LR and ID. For this relationship, significant level is less than $5 \%$. RDINT has significant and positive relationship with Age. If one unit of age increases, RDINT will increase by 0.0368 . It is observed that the most experienced firms spend much amount in Research and Development expenditures as the relationship between the age and R\&D intensity is positive for this study. This result is consistent with past study (Lall, 1983; Subodh, 2002). Gross profit is significantly associated with $R \& D$ but this association is negative. An increase of one unit gross profit will decrease RDINT by 0.1172 . Value of $t$ is -2.06 and $p$ value is 0.043 which is less than $5 \%$. 
Table 5: Regression analysis using fixed effect model

\begin{tabular}{|c|c|c|c|c|c|c|}
\hline \multicolumn{7}{|c|}{. xtreg RDINT AGE GP FV LR GD BOD ID BMF BP, fe } \\
\hline \multicolumn{3}{|c|}{ Fixed-effects (within) regression } & \multicolumn{4}{|c|}{ Number of obs $=128$} \\
\hline \multicolumn{3}{|c|}{ Group variable: Com } & \multicolumn{4}{|c|}{ Number of groups $=32$} \\
\hline \multicolumn{3}{|l|}{ R-sq: } & \multicolumn{4}{|c|}{ Obs per group: } \\
\hline \multicolumn{3}{|c|}{ within $=0.8323$} & \multicolumn{4}{|c|}{$\operatorname{Min}=4$} \\
\hline \multicolumn{3}{|c|}{ between $=0.0317$} & \multicolumn{4}{|c|}{$\operatorname{Avg}=4.0$} \\
\hline \multirow{2}{*}{\multicolumn{3}{|c|}{ overall $=0.0011$}} & \multicolumn{4}{|c|}{$\operatorname{Max}=4$} \\
\hline & & & \multicolumn{4}{|c|}{$\mathrm{F}(9,87)=47.98$} \\
\hline \multicolumn{3}{|c|}{$\operatorname{corr}\left(u_{-}\right.$i, Xb) $=-0.8331$} & \multicolumn{4}{|c|}{ Prob $>F=0.0000$} \\
\hline RDINT & Coef. & Std. Err. & $\mathrm{t}$ & $\mathrm{P}>\mathrm{t}$ & {$[95 \%$ Conf. } & Interval] \\
\hline AGE & .0367809 & .0107051 & 3.44 & 0.001 & .0155033 & .0580585 \\
\hline GP & -.1171931 & .0569959 & -2.06 & 0.043 & -.2304787 & -.0039076 \\
\hline FV & -.1358497 & .0678777 & -2.00 & 0.048 & -.2707639 & -.0009355 \\
\hline LR & .151761 & \begin{tabular}{|c|}
.0128678 \\
\end{tabular} & 11.79 & 0.000 & .1261849 & .177337 \\
\hline GD & .132126 & .2802093 & 0.47 & 0.638 & -.4248204 & .6890725 \\
\hline BOD & .0348556 & \begin{tabular}{|c|c|}
.0228084 \\
\end{tabular} & 1.53 & 0.130 & -.0104785 & .0801898 \\
\hline ID & -.0696058 & .0347878 & -2.00 & 0.049 & -.1387504 & -.0004612 \\
\hline BMF & .0073252 & .0040933 & 1.79 & 0.077 & -.0008108 & .0154611 \\
\hline $\mathrm{BP}$ & -4.630709 & 5.64333 & -0.82 & 0.414 & -15.84744 & 6.58602 \\
\hline cons & 4.274811 & 1.355176 & 3.15 & 0.002 & 1.581251 & 6.96837 \\
\hline sigma_u & \multicolumn{2}{|l|}{.66989548} & \multicolumn{4}{|c|}{ (1) } \\
\hline sigma_e & \multicolumn{2}{|l|}{.08371547} & & & & \\
\hline \multicolumn{7}{|c|}{ Rho.98462315 (fraction of variance due to $\mathrm{u} \_$i) } \\
\hline \multicolumn{7}{|c|}{ F test that all $\mathrm{u} \_\mathrm{i}=0: \mathrm{F}(31,87)=51.87$ Prob $>\mathrm{F}=0.0000$} \\
\hline
\end{tabular}

We can explain that the profitable firms don't want to spend much on $R \& D$ as they are already profitable and it is obvious that less profitable firms will spend much on their Research and Development to make them profitable. Kumar and Saqib (1996) found negative and significant association between gross profit and R\&D activity at 5\% level. Firm value is measured by natural logarithm of assets. This independent variable has negative and significant coefficient with dependent variable. This result differs from some previous literature where significant positive association was obtained between firm size and $R \& D$ (Lee \& Hwang, 2003 ; Min \& Smyth, 2015). The findings show that large firms spend less amount in R\&D. Comparatively small firms prefer to spend much on R\&D.

Posterior independent variable is leverage ratio. This study found significantly positive association between this independent variable 
and the only dependent variable (Research and Development expenditure). Value of $\mathrm{t}$ is $\mathbf{1 1 . 7 9}$ while coefficient is 0.1518 . It indicates that the higher the debt of the firm, the higher the R\&D expenditure is. Several previous literatures found negative association between leverage and R\&D (Chen \& Hsu, 2009 ; Min \& Smyth, 2015). But outcome of this study doesn't find any evidence about negative relationship.

Coefficient between R\&D and independent director is -.0696, which apprises negative association between these two variables. As $\mathrm{t}$ value is 2 , this represents significant relationship. Kor (2006) also found negative association between outsiders on the board and $\mathrm{R} \& \mathrm{D}$ investment, but it was insignificant.

Apart from this, three independent variable namely gender diversity, board of director and board meeting frequency have positive association with R\&D but that is not significant. Relationship between board payment and R\&D is neither positive nor significant.

This narrated result supports hypothesis 1, hypothesis 2 , hypothesis 3 , hypothesis 4 and hypothesis 7. Among all the Hypotheses, these five Hypotheses are accepted as RDINT has significant association with the five respective independent variables. Other hypotheses have been rejected as there is no significant association between RDINT and other independent variables.

\subsection{Conclusion}

Bangladesh is not in a good position in the level of R\&D expenditures in the world. But to ensure economic growth, get competitive
International Journal of Accounting \& Business Finance Vol.6.No.2 December 2020 Issue. pp. 33 - 54

advantage and ensure sustainability some industry has no option to think about R\&D expenditures. For that reason we need to know what factors actually influence $R \& D$ expenditures of manufacturing companies.

Panel data analysis has been used in this study to find out the factors that has effect on R\&D expenditures intensity. A total number of 32 companies were chosen from seven manufacturing industries. Data were considered for four years. The result of the study shows that five independent variables have significant association with research and development expenditures. Here age, gross profit, firm value and leverage are firm specific factors and independent director is corporate governance factor. The findings of this study gives a notation about firm specific and corporate governance factors which affect firm's investment decision like innovation.

The explorative result shows that experienced firms who are conducting business longitudinally invest more in research and development than new firms. Gross profit has significant negative association with dependent variable. So this alludes that firms focus on higher R\&D when they face lower gross profit. Another two firm specific factors, firm value and leverage have significant correlation with R\&D. But impact on dependent variable for first one is negative, while second one is positive. As independent director is negatively and significantly associated with $R \& D$, there is a possibility of having risk averse independent directors in the board.

Different companies of manufacturing industry, regulatory bodies of the country may find the outcome of this study useful. Business owners 
will have more clear idea about the factors that influence R\&D expenditures by which they will be able to take more effective decision for their business. This study result will make the policy makers rethink about the information of $\mathrm{R} \& \mathrm{D}$ expenditures that is disclosed by companies for public uses.

Limitations of this research open up ulterior research opportunities. Consideration of more years in further research can give better idea about the factors influencing research and development expenditures of manufacturing companies of Bangladesh. This study considers only seven manufacturing industries. There are some other industries which can also be used for further study. Specially IT sector is one of the most significant industry in this issue. Only listed companies are considered in this paper. So there is a prospect to conduct research on non-listed manufacturing company too. There is a scope of further research to consider other factors of two categories mentioned in this study as well as to consider factors other than these two classes.

\section{References}

Adams, R. B. \& Ferreira, D. (2009). Women in the board room and their impact on governance and performance. Journal of Financial Economics, 94, 291-309. doi:10.1016/j.jfineco.2008.10.007

Al-Daoud, K. I., Saidin, S. Z. \& Abidin, S. (2016). Board Meeting And Firm Performance: Evidence From The Amman Stock Exchange. Corporate Board: Role, Duties \&, 12(2), 6-11. doi: 10.22495/cbv12i2art1
Becker, B. \& Pain, N. (2008). What Determines Industrial R\&D Expenditure in The Uk? The Manchester School, 76(1), 66-87. doi:10.1111/j.14679957.2007.01050.x

Bhattacharya, M. \& Bloch, H. (2004). Determinants of Innovation. Small Business Economics, 22, 155-162. doi:10.1023/ B:SBEJ.0000014453.94445.de

Burke, R. J. (2003). Women on corporate boards of directors: the timing is right. Women in Management Review, 18(7), 346-348. doi:10.1108/09649420310498966

Chen, H. L. (2012). Board Characteristics and R\&D Investment: Evidence from Taiwan's Electronics Industry. Advances in Management \& Applied Economics, 2(4), 161-170. Retrieved from https://pdfs.semanticscholar.

Chen, H.-L. \& Hsu, W.-T. (2009). Family Ownership, Board Independence, and R\&D Investment. Family Business Review, 22(4), 347-362. doi:10.1177/0894486509341062

Chen, W.-R. \& Miller, K. D. (2007). Situational and Institutional Determinants of Firms' R\&D Search Intensity. Strategic Management Journal, 28, 369-381. doi:10.1002/smj.594

Cohen, W. M. \& Levinthal, D. A. (1989). Innovation and Learning: The Two Faces of $\mathrm{R} \& \mathrm{D}$. The Economic Journal, 99(397), 569-596. doi: $10.2307 / 2233763$ 
Costa-Campi, M., Duch-Brown, N. \& GarciaQuevedo, J. (2014). R\&D Drivers and Obstacles to Innovation in the Energy Industry. Energy Economics, 46, 20 30. doi:10.1016/j.eneco.2014.09.003

Driver, C. \& Guedes, M. J. (2012). Research and Development, Cash Flow, Agency and Governance: UK large companies. Research Policy, 41(9), 1565-1577. doi:10.1016/j. respol.2012.04.003

Ferdaous, D. J. \& Rahman, M. M. (2017). The Effects of Research and Development Expenditure on Firm Performance: an Examination of Pharmaceuticals Industry in Bangladesh. Business \& Entrepreneurship Journal, 6(2), 1-20. Retrieved from http:// www.scienpress.com/Upload/ BEJ\%2fVol\%206_2_1.pdf

Fleming, L. \& Sorenson, O. (2004). Science as a Map in Technological Search. Strategic Management Journal, 25, 909-928. doi:DOI: 10.1002/smj.384

Goyer, M. (2001). Corporate Governance and the Innovation System in France 1985\#2000. Industry and Innovation, 8(2), 135-158. doi:10.1080/1366271012007294 9

Greve, H. R. (2003). A Behavioral Theory of R\&D Expenditures and Innovations: Evidence from Shipbuilding. Academy of Management Journal, 46(6), 685702. doi: $10.5465 / 30040661$

Guldiken, O. \& Darendeli, I. S. (2016). Too much of a good thing: Board International Journal of Accounting \& Business Finance
International Journal of Accounting \& Business Finance Vol.6.No.2 December 2020 Issue. pp. 33 - 54 monitoring and $\mathrm{R} \& \mathrm{D}$ investments. Journal of Business Research, 69, 2931-2938. doi:10.1016/j. jbusres.2015.12.062

Honore, F., Munari, F. \& Potterie, B. V. (2015). Corporate governance practices and companies' R\&D intensity:Evidence from European countries. Research Policy, 44(2), 533-543. doi:10.1016/j. respol.2014.10.016

Kane, M. R., Ubilava, D. \& Xu, P. (2007). Effects of Firm-Specific Factors on R\&D Expenditures of Agribusiness Companies. Retrieved from http://ageconsearch.umn.edu/ bitstream/7332/2/wp070004.pdf

Katila, R. \& Ahuja, G. (2002). Something old, something new: A longitudinal study of search behavior and new product introduction. Academy of Management Journal, 45(6), 11831194. doi:10.2307/3069433

Khan, J. \& Khattak, N. U. (2014). The Significance of Research and Development for Economic Growth: The Case of Pakistan. CURJ, 4(1). Retrieved from https://www.researchgate.net/ publication/272176830_The Significance_of_Research_And_ Development_For_Economic Growth_The_Case_of_Pakistan

Kor, Y. Y. (2006). Direct and interaction effects of top management team and board compositions on R\&D investment strategy. Strategic Management 
Journal, 27, 1081-1099. doi:10.1002/ smj.554

Kumar, N. \& Aggarwal, A. (2005). Liberalization, outward orientation and in-house R\&D activity of multinational and local firms: A quantitative exploration for Indian manufacturing. Research Policy, 34(4), 441-460. doi:10.1016/j. respol.2005.01.010

Kumar, N. \& Saqib, M. (1996). Firm size, opportunities for adaptation and inhouse R \& D activity in developing countries: the case of Indian manufacturing. Research Policy, 25(5), 713-722. doi:10.1016/00487333(95)00854-3

Lall, S. (1983). Determinants of $R \& D$ in an LDC The Indian Engineering Industry. Economics Letters, 13, 379383.

Lee, M.-H. \& Hwang, I. J. (2003). Determinants of Corporate R\&D Investment: An Empirical Study Comparing Korea's IT Industry with Its Non-IT Industry. ETRI Journal, 25, 258-265.

Limanli, o. (2015). Determinants of R\&D Investment Decision in Turkey. Procedia - Social and Behavioral Sciences, 759-767. Retrieved from http://creativecommons.org/licenses/ by-nc-nd/4.0/

Mahlich, J. C. \& Roediger-Schluga, T. (2006). The Determinants of Pharmaceutical R\&D Expenditures: Evidence from Japan. Review of Industrial
International Journal of Accounting \& Business Finance Vol.6.No.2 December 2020 Issue. pp. 33 - 54

Organization, 28(2), 145-164. doi:0.1007/s1 1151 -006-001 0-z

Min, B. S. \& Smyth, R. (2015). Determinants of R\&D intensity and its impact on firm value in an innovative economy in which family business groups are dominant:The case of South Korea. Retrieved from https://ideas.repec. org/p/mos/moswps/2015-25.html

NISHI, T. (2015). Different Board Structures and R\&D: Evidence from Japanese Corporation. Corporate Board: Role, Duties \& Composition, 11(2-1), 171182. doi:10.22495/cbv11i2c1art3

Nohria, N. \& Gulati, R. (1996). Is slack good or bad for innovation? Academy of Management Journal, 39(5), 12451264. Retrieved from https://doi. org/10.5465/256998

OECD Factbook. (2015-2016). Economic, Environmental and Social Statistics.

Othman, R., \& Ameer, R. (2009). Determinants and persistence of research and development investments: Evidence from Malaysia. International Journal of Emerging Markets, 275-292. doi:10.1108/17468800910968427

Pamukcu, T. (2003). Trade Liberalization and Innovation Decisions of Firms: Lessons from Post-1980 Turkey. World Development, 31(8), 1443-1458. doi:10.1016/s0305750x(03)00087-1

Pamukcu, T. \& Utku-Ismihan, F. M. (2009). Determinants of R\&D 
Decisions of Firms in Developing Countries the Case of Turkey. Paper presented at EconAnadolu 2009: Anadolu International Conference in Economics. Eskişehir, Turkey. Retrieved from https://www.semanticscholar. org/paper/Determinants - ofR\%26D-Decisions-of-Firms-inCountries-Pamuk\%C3\%A7u-Utku\%C4\%B0smihan//c4dda194ec8b50 ee360949e4d966 308df0c61ec3

Panda, B., \& Leepsa, N. M. (2017). Agency theory: Review of Theory and Evidence on Problems and Perspectives. Indian Journal of Corporate Governance, 10(1), 74-95. doi:10.1177/0974686217701467

Shapiro, D., Tang, Y., Wang, M. \& Zhang, W. (2015). The effects of corporate governance and ownership on the innovation performance of Chinese SMEs. Journal of Chinese Economic and Business Studies, 13(4), 311-335. doi:10.1080/14765284.2015.1090267
International Journal of Accounting \& Business Finance Vol.6.No.2 December 2020 Issue. pp. 33 - 54

Subodh, K. (2002). Market Concentration, Firm Size and Innovative Activity: A Firm-level Economic Analysis of Selected Indian Industries under Economic Liberalization. WIDER Discussion Paper No. 2002/108.

Williamson, O. E. (1988). Corporate Finance and Corporate Governance. THE JOURNAL OF FINANCE, XLIII(3), 567-591. doi:10.2307/2328184

Yanghua, C. (2010). Ownership Structure, Financial Structure and $R \& D$ Investments: Evidence from Korean Firms. Master Thesis. Retrieved from https://ink.library.smu.edu.sg/ etd_coll/ 69

Zemplinerova, A. \& Hromadkova, E. (2012). Determinants of Firm's Innovation. Prague Economic Papers, 487-503. doi:10.18267/j.pep.436 


\section{Appendices}

Table A-1. Regression Analysis

\begin{tabular}{|c|c|c|c|c|c|c|}
\hline \multicolumn{7}{|c|}{ Reg RDINT AGE GP FV LR GD BOD ID BMF BP } \\
\hline & & & & & \multicolumn{2}{|c|}{ Number of obs $=128$} \\
\hline Source & SS & \multicolumn{2}{|l|}{ Df } & MS & \multicolumn{2}{|c|}{$\mathrm{F}(9,118)=6.38$} \\
\hline Model & 5.78025241 & \multicolumn{2}{|l|}{9} & .642250268 & \multicolumn{2}{|c|}{ Prob $>F=0.0000$} \\
\hline Residual & 11.8777934 & \multicolumn{2}{|l|}{118} & .100659266 & \multicolumn{2}{|c|}{ R-squared $=0.3273$} \\
\hline Total & 17.6580458 & \multicolumn{2}{|l|}{127} & .139039731 & \multicolumn{2}{|c|}{ Adj R-squared $=0.2760$} \\
\hline \multicolumn{7}{|c|}{\begin{tabular}{l|l} 
& Root MSE $=.31727$
\end{tabular}} \\
\hline RDINT & Coef. & Std. Err. & $\mathrm{t}$ & $\mathrm{P}>\mathrm{t}$ & [95\% Conf. & Interval] \\
\hline AGE & -.0066386 & .0026409 & -2.51 & 0.013 & -.0118684 & -.0014088 \\
\hline GP & -.0095747 & .0602037 & -0.16 & 0.874 & -.1287944 & .1096449 \\
\hline FV & .0938062 & .0524568 & 1.79 & 0.076 & -.0100727 & .197685 \\
\hline LR & .0916737 & .0197717 & 4.64 & 0.000 & .0525202 & .1308271 \\
\hline GD & -.2566294 & .1874868 & -1.37 & 0.174 & -.6279044 & .1146456 \\
\hline BOD & -.0305107 & .0233668 & -1.31 & 0.194 & -.0767834 & .0157619 \\
\hline ID & .1202522 & .0740897 & 1.62 & 0.107 & -.0264656 & .26697 \\
\hline BMF & -.0030945 & .0045933 & -0.67 & 0.502 & -.0121904 & .0060015 \\
\hline $\mathrm{BP}$ & 49.05528 & 11.20427 & 4.38 & 0.000 & 26.86778 & 71.24278 \\
\hline cons & -1.677376 & .6614724 & -2.54 & 0.013 & -2.987271 & -.3674803 \\
\hline
\end{tabular}

Table A-2. Regression Analysis using fixed effect model

\begin{tabular}{|c|c|c|c|c|c|c|}
\hline \multicolumn{7}{|c|}{. xtreg RDINT AGE GP FV LR GD BOD ID BMF BP,fe } \\
\hline \multicolumn{4}{|c|}{ Fixed-effects (within) regression } & \multicolumn{3}{|c|}{ Number of obs $=128$} \\
\hline \multicolumn{4}{|c|}{ Group variable: Com } & \multicolumn{3}{|c|}{ Number of groups $=32$} \\
\hline \multicolumn{4}{|l|}{ R-sq: } & \multicolumn{3}{|c|}{ Obs per group: } \\
\hline \multicolumn{4}{|c|}{ within $=0.8323$} & \multicolumn{3}{|l|}{$\operatorname{Min}=4$} \\
\hline \multicolumn{4}{|c|}{ between $=0.0317$} & \multicolumn{3}{|c|}{ Avg $=4.0$} \\
\hline \multicolumn{4}{|c|}{ overall $=0.0011$} & \multicolumn{3}{|c|}{$\operatorname{Max}=4$} \\
\hline & \multicolumn{3}{|c|}{$\mathrm{F}(9,87)=47.98$} \\
\hline \multicolumn{4}{|c|}{$\operatorname{corr}\left(\mathrm{u} \_\mathrm{i}, \mathrm{Xb}\right)=-0.8331$} & \multicolumn{3}{|c|}{ Prob $>F=0.0000$} \\
\hline RDINT & Coef. & Std. Err. & $\mathrm{t}$ & $\mathrm{P}>\mathrm{t}$ & {$[95 \%$ Conf } & Interval] \\
\hline AGE & .0367809 & .0107051 & 3.44 & 0.001 & .0155033 & .0580585 \\
\hline GP & -.1171931 & .0569959 & -2.06 & 0.043 & -.2304787 & -.0039076 \\
\hline FV & -.1358497 & .0678777 & -2.00 & 0.048 & -.2707639 & -.0009355 \\
\hline LR & .151761 & .0128678 & 11.79 & 0.000 & .1261849 & .177337 \\
\hline
\end{tabular}




\begin{tabular}{|l|l|l|l|l|ll|}
\hline GD & .132126 & .2802093 & 0.47 & 0.638 & -.4248204 & .6890725 \\
\hline BOD & .0348556 & .0228084 & 1.53 & 0.130 & -.0104785 & .0801898 \\
\hline ID & -.0696058 & .0347878 & -2.00 & 0.049 & -.1387504 & -.0004612 \\
\hline BMF & .0073252 & .0040933 & 1.79 & 0.077 & -.0008108 & .0154611 \\
\hline BP & -4.630709 & 5.64333 & -0.82 & 0.414 & -15.84744 & 6.58602 \\
\hline cons & 4.274811 & 1.355176 & 3.15 & 0.002 & 1.581251 & 6.96837 \\
\hline sigma_u & .66989548 & & & & \\
\hline sigma_e & .08371547 & & & \\
\hline
\end{tabular}

Table A-3. Regression Analysis using random effect model

\begin{tabular}{|c|c|c|c|c|c|c|}
\hline \multicolumn{7}{|c|}{ xtreg RDINT AGE GP FV LR GD BOD ID BMF BP,re } \\
\hline \multicolumn{3}{|c|}{ Random-effects GLS regression } & \multicolumn{4}{|c|}{ Number of obs $=128$} \\
\hline \multicolumn{3}{|c|}{ Group variable: Com } & \multicolumn{4}{|c|}{ Number of groups $=32$} \\
\hline \multicolumn{3}{|l|}{ R-sq: } & \multicolumn{4}{|c|}{ Obs per group: } \\
\hline \multicolumn{3}{|c|}{ within $=0.8059$} & \multicolumn{4}{|l|}{$\operatorname{Min}=4$} \\
\hline \multicolumn{3}{|c|}{ between $=0.0113$} & \multicolumn{4}{|c|}{$\mathrm{Avg}=4.0$} \\
\hline \multirow{2}{*}{\multicolumn{3}{|c|}{ overall $=0.1318$}} & \multicolumn{4}{|l|}{$\operatorname{Max}=4$} \\
\hline & & & \multicolumn{4}{|c|}{ Wald chi2 $(10)=356.63$} \\
\hline \multicolumn{3}{|c|}{ corr $\left(\mathrm{u} \_\mathrm{i}, \mathrm{X}\right)=0$ (assumed) } & \multicolumn{4}{|c|}{ Prob $>$ chi $2=0.0000$} \\
\hline RINT & Coef. & Std. Err. & $\mathrm{z}$ & $\mathrm{P}>\mathrm{Z}$ & {$[95 \%$ Conf. } & Interval] \\
\hline Age & .0012568 & .0044284 & 0.28 & 0.777 & -.0074226 & .0099363 \\
\hline LnGP & -.061491 & .0522005 & -1.18 & 0.239 & -.1638021 & .0408202 \\
\hline LnAsset & .0453395 & .0504348 & 0.90 & 0.369 & -.0535109 & .1441899 \\
\hline Leverage & .1248799 & .0107221 & 11.65 & 0.000 & .1038648 & .1458949 \\
\hline GD & -.1563101 & .2298369 & -0.68 & 0.496 & -.6067821 & .294162 \\
\hline BOD & .0228249 & .0216796 & 1.05 & 0.292 & -.0196663 & .0653161 \\
\hline ID & -.0293832 & .0350157 & -0.84 & 0.401 & -.0980128 & .0392464 \\
\hline $\mathrm{BMF}$ & .0046815 & .00391 & 1.20 & 0.231 & -.002982 & .012345 \\
\hline $\mathrm{BP}$ & 5.707485 & 5.433875 & 1.05 & 0.294 & -4.942714 & 16.35768 \\
\hline cons & .1028574 & .9477064 & 0.11 & 0.914 & -1.754613 & 1.960328 \\
\hline \multicolumn{7}{|c|}{ sigma_u.31986448 } \\
\hline \multicolumn{7}{|c|}{ sigma_e.08371547 } \\
\hline \multicolumn{7}{|c|}{ Rho.93589298 (fraction of variance due to $\mathrm{u}$ i) } \\
\hline
\end{tabular}

Table A-4. Hausman test 


\begin{tabular}{|l|l|l|l|l|}
\hline \multicolumn{5}{|l|}{ hausman fixed, sigmamore } \\
\hline \multicolumn{5}{|l|}{ Coefficients ---- } \\
& $($ b) & (B) & b-B & sqrt(diag(V_b-V_B)) \\
& Fixed & Random & Difference & S.E. \\
\hline AGE & .0367809 & .0012568 & .035524 & .0106675 \\
\hline GP & -.1171931 & -.061491 & -.0557021 & .0325077 \\
\hline FV & -.1358497 & .0453395 & -.1811891 & .0531019 \\
\hline LR & .151761 & .1248799 & .0268811 & .0088197 \\
\hline GD & .132126 & -.1563101 & .2884361 & .1964119 \\
\hline BOD & .0348556 & .0228249 & .0120307 & .0116444 \\
\hline ID & -.0696058 & -.0293832 & -.0402226 & .0135165 \\
\hline BMF & .0073252 & .0046815 & .0026437 & .0020535 \\
\hline BP & -4.630709 & 5.707485 & -10.33819 & 2.747102 \\
\hline
\end{tabular}

